Article

\title{
Enhanced Arsenic Tolerance in Triticum aestivum Inoculated with Arsenic-Resistant and Plant Growth Promoter Microorganisms from a Heavy Metal-Polluted Soil
}

\author{
Javiera Soto ${ }^{1,2}$, Javier Ortiz ${ }^{1}$, Hector Herrera ${ }^{1}$, Alejandra Fuentes ${ }^{1}$, Leonardo Almonacid ${ }^{1}$, \\ Trevor C. Charles ${ }^{3}$ and César Arriagada ${ }^{1, *(\mathbb{D})}$ \\ 1 Laboratorio de Biorremediación, Facultad de Ciencias Agropecuarias y Forestales, \\ Universidad de La Frontera, Francisco Salazar, Temuco 01145, Chile \\ 2 Programa de Doctorado en Ciencias mención Biología Celular y Molecular, Universidad de La Frontera, \\ Francisco Salazar, Temuco 01145, Chile \\ 3 Department of Biology, University of Waterloo, University Avenue West, Waterloo, ON N2L 3G1, Canada \\ * Correspondence: cesar.arriagada@ufrontera.cl; Tel.: +56-452-325-662
}

Received: 14 August 2019; Accepted: 7 September 2019; Published: 12 September 2019

check for updates

\begin{abstract}
In soils multi-contaminated with heavy metal and metalloids, the establishment of plant species is often hampered due to toxicity. This may be overcome through the inoculation of beneficial soil microorganisms. In this study, two arsenic-resistant bacterial isolates, classified as Pseudomonas gessardii and Brevundimonas intermedia, and two arsenic-resistant fungi, classified as Fimetariella rabenhortii and Hormonema viticola, were isolated from contaminated soil from the Puchuncaví valley (Chile). Their ability to produce indoleacetic acid and siderophores and mediate phosphate solubilization as plant growth-promoting properties were evaluated, as well as levels of arsenic resistance. A real time PCR applied to Triticum aestivum that grew in soil inoculated with the bacterial and fungal isolates was performed to observe differences in the relative expression of heavy metal stress defense genes. The minimum inhibitory concentration of the bacterial strains to arsenate was up to $7000 \mathrm{mg} \cdot \mathrm{L}^{-1}$ and that of the fungal strains was up to $2500 \mathrm{mg} \cdot \mathrm{L}^{-1}$. P. gessardi was able to produce siderophores and solubilize phosphate; meanwhile, B. intermedia and both fungi produced indoleacetic acid. Plant dry biomass was increased and the relative expression of plant metallothionein, superoxide dismutase, ascorbate peroxidase and phytochelatin synthase genes were overexpressed when $P$. gessardii plus $B$. intermedia were inoculated.
\end{abstract}

Keywords: arsenic contamination; oxidative stress; plant growth promotion; soil microorganisms

\section{Introduction}

Arsenic (As) is a toxic metalloid that is distributed extensively in the environment due to natural geochemical processes and anthropogenic activities. Environmental As can derive from several natural sources such as volcanoes, marine sedimentary rocks and fossil fuels, although mainly from anthropogenic activities, including metal smelting, mining, agricultural chemicals (pesticides), wood preservatives and industrial activities [1,2]. Soil contamination with As has become a serious environmental and human hazard. The US Environmental Protection Agency [3] lists As as a carcinogenic substance. It exists in the environment mainly as oxyanions of trivalent arsenite As(III) or pentavalent arsenate As(V), with As(III) being more toxic than As(V) in biological systems [4]. There is a structural similarity between arsenate and inorganic phosphate, so it can enter the cell easily 
through the same transport system as phosphate. This mimicry allows arsenate to alter phosphate metabolism $[5,6]$.

Arsenic is toxic to plants because it interferes with their metabolism, causing disorders at various levels of organization, inhibiting plant growth [5]. Arsenic is accumulated predominantly in the root system, where the metalloid inhibits biomass accumulation [7-9]. At elevated concentrations, As hampers critical metabolic processes, which can lead to plant death [10]. Several plants have developed mechanisms to sequester As in the roots; however, As can be translocated to other plant tissues, altering growth and yield, causing discoloration and plasmolysis of the root, wilting and necrosis of the apex and contour of the leaves, inhibition of chlorophyll biosynthesis, and a decrease in photosynthetic capacity [11,12].

Plants have developed a series of strategies to withstand the toxicity of arsenic, such as i) the reduction of $\mathrm{As}(\mathrm{V})$ to $\mathrm{As}(\mathrm{III})$; ii) As(III) chelation by glutathione; iii) chelation by phytochelatins (PC); iv) the sequestration of As complexes in vacuoles $[13,14]$. Within the plant cell, As(V) interferes with oxidative phosphorylation and the synthesis of ATP in the mitochondria by replacing phosphate [15], whereas As(III) binds to sulfhydryl groups, with the consequent detrimental effects on protein function $[13,16]$. Likewise, As toxicity is caused by the effects of oxidative stress, although the exact molecular mechanisms affected are still not clear [17].

Recent studies have shown that microorganisms isolated from heavy metal-polluted soils can effectively promote plant growth [18-20]. When considering approaches to alter the mobilization of heavy metals, there are several advantages of using microorganisms instead of chemical methods, since metabolites produced by microorganisms are biodegradable, less toxic and can be produced in situ [21]. In addition, microorganisms associated with plants are able to produce growth-regulating substances such as siderophores and indoleacetic acid, and mediate phosphate solubilization, which increases the growth of plants in a soil contaminated with metals [22-24]. We hypothesized that the inoculation of bacterial and fungal strains isolated from heavy metal-polluted soils promotes plant growth when they are subjected to high concentrations of arsenic and generate greater tolerance to oxidative stress. Therefore, the aims of this study were to characterize the production of some secondary metabolites, such as indoleacetic acid, phosphate solubilization and siderophores, from arsenic-tolerant bacteria and fungi isolated from the rhizosphere of metallophyte plants and to evaluate the effects of these microorganisms on reducing oxidative stress and promotion of the plant growth of wheat plants grown in a metal-polluted soil.

\section{Materials and Methods}

\subsection{Study Site}

The soils used in this study were collected from a rhizospheric area, i.e., the closest region of the soil that is directly influenced by root exudates of Oenothera picensis plants located in the Puchuncaví Valley in the coastal area of central Chile (V Region), $1.5 \mathrm{~km}$ southeast of the Ventanas copper smelter $\left(32^{\circ} 46^{\prime} 30^{\prime \prime} \mathrm{S} ; 71^{\circ} 28^{\prime} 17^{\prime \prime} \mathrm{W}\right)$ that has been subjected to large quantities of gaseous and metal-rich particulate pollution from the copper smelter since 1964 [25]. The soil is classified as an Entisol and has a pH of 5.54 and $2.41 \%$ organic matter [26]. Characteristics of the soils used are described in Table 1. The $\mathrm{pH}$ of soil samples was determined in a 1:2.5 $(\mathrm{v} / \mathrm{v})$ suspension of soil in $\mathrm{H}_{2} \mathrm{O}$. Electrical conductivity (CE) was measured on samples at a ratio of 1:5 (sample: water) and shaken for $30 \mathrm{~min}$. Organic matter was determined by wet digestion using the Walkley and Black [27] method. Total N concentration was obtained using the Kjeldahl method. Olsen-P was measured using the Olsen P test, in which inorganic $\mathrm{P}$ is extracted from soil with $0.5 \mathrm{M} \mathrm{NaHCO}_{3}$ at $\mathrm{pH} 8.5$ [28]. Available $\mathrm{K}$ and total concentrations of heavy metals $(\mathrm{Cu}, \mathrm{Zn}, \mathrm{Cd}$ and $\mathrm{Pb})$ were determined as described by Mingorance [29]. 
Table 1. Chemical analysis of the soil sample from the Puchuncaví Valley.

\begin{tabular}{|c|c|}
\hline pH (Water) & $5.54 \pm 0.13$ \\
\hline Electrical conductivity (CE) $\left(\mathrm{dS} \mathrm{L}^{-1}\right)$ & $0.1 \pm 0.09$ \\
\hline Organic matter (\%) & $2.41 \pm 0.16$ \\
\hline $\mathrm{N}$ total $(\%)$ & $0.1 \pm 0.02$ \\
\hline $\mathrm{N}$ available $\left(\mathrm{mg} \cdot \mathrm{kg}^{-1}\right)$ & $28.7 \pm 1.78$ \\
\hline$P$ available $\left(\mathrm{mg} \cdot \mathrm{kg}^{-1}\right)$ & $40.3 \pm 3.47$ \\
\hline K interchangeable $\left(\mathrm{mg} \cdot \mathrm{kg}^{-1}\right)$ & $210 \pm 8.21$ \\
\hline $\mathrm{Cu}$ total $\left(\mathrm{mg} \cdot \mathrm{kg}^{-1}\right)$ & $385 \pm 14.53$ \\
\hline $\mathrm{Zn}$ total $\left(\mathrm{mg} \cdot \mathrm{kg}^{-1}\right)$ & $183 \pm 7.93$ \\
\hline Cd total $\left(\mathrm{mg} \cdot \mathrm{kg}^{-1}\right)$ & $1.1 \pm 0.07$ \\
\hline $\mathrm{Pb}$ total $\left(\mathrm{mg} \cdot \mathrm{kg}^{-1}\right)$ & $135 \pm 6.91$ \\
\hline As total $\left(\mathrm{mg} \cdot \mathrm{kg}^{-1}\right)$ & $52 \pm 3.65$ \\
\hline
\end{tabular}

\subsection{Isolation of Bacteria and Fungi and Their Resistance to Arsenic}

Bacteria and fungi were isolated from the rhizospheric heavy metal-polluted soil samples described above. Bacteria were isolated by adding $1 \mathrm{~g}$ of homogenized soil to $10 \mathrm{~mL}$ of sterile distilled water, and shaking at $100 \mathrm{rpm}$ for $5 \mathrm{~min}$. The mixture was serially diluted, and $0.1 \mathrm{~mL}$ aliquots were plated onto LB (Luria-Bertani) agar plates (10 $\mathrm{g}$ tryptone, $10 \mathrm{~g} \mathrm{NaCl}, 5 \mathrm{~g}$ yeast extract, $12 \mathrm{~g}$ agar per liter) and incubated at $27^{\circ} \mathrm{C}$ for $48 \mathrm{~h}$. After growth, a number of different colonies were purified. The fungi were isolated according to the method described by Bissett and Widden [30]. The isolated fungi were kept in plates with potato dextrose agar (PDA) culture medium at $4{ }^{\circ} \mathrm{C}$ with periodic subculture. Pure cultures of a total of 10 bacteria and 8 fungi were obtained, based on their different macroscopic characteristics (colonial morphology, color, texture, shape, and diameter).

The isolated bacterial and fungal strains were tested for their tolerance to $\mathrm{As}(\mathrm{V})$ as sodium arsenate $\left(\mathrm{Na}_{2} \mathrm{HAsO}_{4} \cdot 7 \mathrm{H}_{2} \mathrm{O}\right)$ and sodium (meta)arsenite $\left(\mathrm{NaAsO}_{2}\right)$ (Sigma-Aldrich, St. Louis, MS, USA). LB broth and PDA were used for $\mathrm{As}(\mathrm{V})$ and $\mathrm{As}(\mathrm{III})$ experiments. Bacterial strains were cultured in modified LB broth that was supplemented with $\mathrm{As}(\mathrm{V})$ and $\mathrm{As}(\mathrm{III})$. The concentrations used ranged from 500 to 8000 which increased $500 \mathrm{mg} \cdot \mathrm{L}^{-1}$ each time. The strains were cultured in an orbital shaker at $27^{\circ} \mathrm{C}$ for $72 \mathrm{~h}$, and growth was monitored by measuring their OD600. Fungal strains were placed in the center of Petri dishes containing PDA plus $\mathrm{As}(\mathrm{V})$ and $\mathrm{As}(\mathrm{III})$, the concentration ranged between 500 and $3000 \mathrm{mg} \cdot \mathrm{L}^{-1}$, which increased $500 \mathrm{mg} \cdot \mathrm{L}^{-1}$ each time, and were incubated for 21 days at $27^{\circ} \mathrm{C}$. Fungal growth was measured in $\mathrm{mm}$. Among the microorganisms tested, two bacteria (designated as strains B4 and B10) and two fungi (designated as strains V7 and V8) were finally chosen for the following experiments for their ability to resist high concentrations of $\mathrm{As}(\mathrm{V})$ and $\mathrm{As}(\mathrm{III})$.

\subsection{Molecular Characterization}

Bacterial DNA extraction was made using the UltraClean ${ }^{\circledR}$ Microbial DNA Isolation Kit (MO-BIO Laboratories, Carlsbad, CA, USA) according to the manufacturer's instructions. Molecular identification of bacteria was performed by amplification of $16 \mathrm{~S}$ rDNA gene through PCR according to Banerjee, et al. [31] using 27F (5'-AGAGTTTGATCCTGGCTCAG-3') and 1492R (5'-TACGGTTACCTTGTTAC GACTT-3') primers. DNA extraction of the fungi was done using the DNeasy Plant Mini Kit (QIAGEN, Hilden, Germany) and subsequent PCR amplification of the $18 \mathrm{~S}$ rDNA with the universal primers ITS1 and ITS4 [32] following the PCR conditions described in Herrera, et al. [33]. DNA sequencing was performed by Macrogen (Seoul, Korea). A BLAST (Basic Local Alignment Search Tool) search against the GenBank database (http://www.ncbi.nlm.nih.gov/) was conducted to find the closest known sequences of microorganisms.

\subsection{Screening of Potential Plant Growth-Promoting Traits}

Production of siderophores was determined according to Milagres, et al. [34]. Chrome azurol S (CAS) (Sigma-Aldrich, St. Louis, MO, USA) was prepared according to Schwyn and Neilands [35]. 
A volume of $20 \mathrm{~mL}$ of LB agar or PDA medium was dispensed into Petri dishes. After that, the solidified medium was cut into halves, one of which was replaced by CAS-blue agar. The bacteria and fungi were inoculated in the center of the two solidified media and incubated at $27^{\circ} \mathrm{C}$ in the dark for 5 days. The CAS reaction rate was determined by the color-change front in the CAS-blue agar, expressed as (+) when the color change was present, and as (-) when it was not.

To measure indoleacetic acid production (IAA), bacterial and fungal isolates were transferred to sucrose minimal salt (SMS) medium $\left(10 \mathrm{~g} \cdot \mathrm{L}^{-1}\right.$ sucrose, $2 \mathrm{~g} \cdot \mathrm{L}^{-1} \mathrm{~K}_{2} \mathrm{HPO}_{4}, 1 \mathrm{~g} \cdot \mathrm{L}^{-1}\left(\mathrm{NH}_{4}\right)_{2} \mathrm{SO}_{4}, 0.5 \mathrm{~g} \cdot \mathrm{L}^{-1}$ $\mathrm{MgSO}_{4}, 0.5 \mathrm{~g} \cdot \mathrm{L}^{-1}$ yeast extract, $0.5 \mathrm{~g} \cdot \mathrm{L}^{-1} \mathrm{CaCO}_{3}, 0.1 \mathrm{~g} \cdot \mathrm{L}^{-1} \mathrm{NaCl}, \mathrm{pH}$ 7.2) and 1/7 PDB, respectively, both supplemented with $500 \mathrm{mg} \cdot \mathrm{mL}^{-1}$ L-tryptophan and $250 \mathrm{mg} \cdot \mathrm{L}^{-1}$ of sodium arsenate. The cultures were incubated in an orbital shaker at $27^{\circ} \mathrm{C}$ for $48 \mathrm{~h}$ (bacteria) and $7 \mathrm{~d}$ (fungi). The culture solution was centrifuged at $2000 \mathrm{~g}$ for $20 \mathrm{~min}$, and a $0.5 \mathrm{~mL}$ portion of the supernatant was mixed with $2 \mathrm{~mL}$ of Salkowski's reagent [36]. The absorbance of the mixture was measured at $530 \mathrm{~nm}$ after $25 \mathrm{~min}$ of reaction. Pure IAA was used as a standard, and the concentration of the extracts was calculated and expressed in $\mu \mathrm{g} \mathrm{L}^{-1}$. To determine phosphate solubilization, the bacterial and fungal strains were inoculated on Pikovskaya agar (HiMedia Laboratories, Dindori, India) medium and incubated for $120 \mathrm{~h}$ at $28^{\circ} \mathrm{C}$. Their phosphorus solubilizing activity was then determined by measuring the size of the halo formed by the solubilization of insoluble phosphate [37]. The results are shown as positive (+) or negative (-) solubilization.

\subsection{Establishment of Plants and Inoculations}

The experiments were carried out using Triticum aestivum var PANTERA-INIA due to its rapid growth, good performance in the heavy metal-polluted soil used, and the availability of extensive molecular information in the databases. Seeds were sterilized with $0.05 \% \mathrm{NaClO}$ for 15 min under agitation and rinsed with abundant sterile distilled water; they were sown in vermiculite and left in darkness until germination. After ten days, three seedlings were transplanted to $300 \mathrm{cc}$ pots with Puchuncaví Valley soil, sterilized in an autoclave for three consecutive days, supplemented with $40 \mathrm{~mL}$ of 0 and $300 \mathrm{mg} \cdot \mathrm{L}^{-1}$ of $\mathrm{As}(\mathrm{V})$ which was previously incubated for 14 days.

The bacterial and fungal strains were inoculated to the soil individually and together (the 2 bacteria mixed, and the 2 fungi mixed). A volume of $10 \mathrm{~mL}$ of a solution of distilled water with each bacterium was taken at an optical density of 0.5 measured at $600 \mathrm{~nm}$. For the fungi, a Petri dish with fungal hyphae covering the total surface was crushed and diluted in $40 \mathrm{~mL}$ of sterile distilled water. For each pot, $10 \mathrm{~mL}$ of each solution was inoculated. Plants were cultivated in a greenhouse for 14 days and then transferred to the growth chamber with light provided by Sylvania (Middleton, MA, USA) incandescent lamps-cold white light $\left(400 \mathrm{E} \mathrm{m}^{-2} \mathrm{~s}^{-1}, 500-700 \mathrm{~nm}\right)$, with a cycle of $16 / 8 \mathrm{~h}$ day/night at $24 / 16^{\circ} \mathrm{C}$ and $50 \%$ relative humidity. Each treatment consisted of 12 replicates and the plants were harvested after 20 days. Shoot and root dry biomass was determined using a forced air stove $\left(65^{\circ} \mathrm{C}\right.$ for $72 \mathrm{~h}$ ), weighed on a digital scale and expressed in grams. The total As content in T. aestivum was determined as described by Mingorance [29]. Plants were frozen in liquid nitrogen and stored at $-80^{\circ} \mathrm{C}$ for further analyses.

The experiment design consisted of: (i) control, (ii) the inoculation of bacteria ((1) P.gessardii, (2) B. intermedia, and (3) P.gessardii plus B. intermedia) and fungi ((4) F. rabenhortii, (5) H. viticola, and (6) F. rabenhortii plus H. viticola) to Triticum aestivum plants (iii) growing under 0 and $300 \mathrm{mg} \mathrm{K}^{-1}$ of As. There were 14 treatments with 12 biological replicates.

\subsection{Soil Biochemical Properties}

To observe some possible soil biochemical changes, we studied acid phosphatase activity and it was measured using $p$-nitrophenyl phosphate (PNPP) (Sigma-Aldrich, St. Louis, MS, USA) as a substrate, according to the method described by Gianfreda, et al. [38]. The $\beta$-glucosidase activity was determined by detection of $p$-nitrophenol (PNP) released from $p$-nitrophenyl- $\beta$-D-glucopyranoside (PNG) (Sigma-Aldrich, St. Louis, MS, USA). In both assays, the amount of PNP formed was determined 
by spectrophotometry at $398 \mathrm{~nm}$ [39]. The hydrolysis of fluorescein diacetate (FDA) as an indicator of the total microbial activity of soil was determined according to Adam and Duncan [40] and expressed as $\mu \mathrm{g}$ fluorescein released per $\mathrm{g}$ of dry soil. The final concentration of FDA was measured as the absorbance at $490 \mathrm{~nm}$.

\subsection{Real-Time $P C R$}

Total RNA was isolated from $100 \mathrm{mg}$ of leaves using the RNA-Solv reagent (E.Z.N.A. ${ }^{\circledR}$, Omega Bio-tek, Norcross, GA, USA) following the manufacturer's instructions where the centrifugation temperature was modified to $4{ }^{\circ} \mathrm{C}$. The samples were treated with RNase-free DNase I Set (E.Z.N.A. ${ }^{\circledR}$ ) and purified using HiBind RNA mini Columns (E.Z.N.A. $\left.{ }^{\circledR}\right)$. The concentration and purity of the extracted RNA were determined using an Infinite ${ }^{\circledR} 200$ NanoQuant Plate ${ }^{\mathrm{TM}}$ (TECAN, Seestrasse, Switzerland). RNA quality was verified by denaturing agarose gel visualization. Primers for real-time PCR analyses were designed from mRNA sequences of Triticum aestivum stored in the NCBI database (http://www.ncbi.nlm.nih.gov/). Each primer was tested in silico in an attempt to avoid dimer formation. Target genes (superoxide dismutase, ascorbate peroxidase, metallothionein, and phytochelatin) are related to heavy metal stress defense genes. The genes GAPDH, $\alpha$-TUB and EF1 $\alpha$ were chosen as candidates for reference genes. Descriptions of the designed primers are shown in Table 2.

The synthesis of the first strand of cDNA was obtained from $1 \mu \mathrm{g}$ total RNA using the AffinityScript cDNA Synthesis Kit (Agilent Technologies, Santa Clara, CA, USA) following the manufacturer's instructions. The qPCR reaction was performed in a final volume of $20 \mu \mathrm{L}$, using $2 \mu \mathrm{L}$ of pre-diluted cDNA 1:10 and a mixture of $0.625 \mu \mathrm{L}$ of each primer $(10 \mu \mathrm{M}), 10 \mu \mathrm{L}$ of PowerUp ${ }^{\text {TM }}$ SYBR $^{\text {TM }}$ Green Master Mix (Applied Biosystems ${ }^{\mathrm{TM}}$, Foster City, CA, USA) and $7.5 \mu \mathrm{L}$ of nuclease-free water. For the negative control, the same reaction without template was used. Real-time PCR was carried out in a StepOnePlus Thermocycler (Applied Biosystems ${ }^{\mathrm{TM}}$, Foster City, CA, USA) using the following thermal profile: $10 \mathrm{~min}$ at $95{ }^{\circ} \mathrm{C}$ and 40 cycles of $15 \mathrm{~s}$ at $95{ }^{\circ} \mathrm{C}, 15 \mathrm{~s}$ at $60{ }^{\circ} \mathrm{C}$, and $15 \mathrm{~s}$ at $72{ }^{\circ} \mathrm{C}$. Data were processed using the Gene Expression Analysis for iCycler iQ real-time PCR Detection System software (BioRad Laboratories, Hercules, CA, USA).

Table 2. Set of primers used for real-time PCR.

\begin{tabular}{|c|c|c|c|c|}
\hline Gene & Function & & Primers $5^{\prime}-3^{\prime}$ & $\begin{array}{c}\text { Amplicon Length } \\
(\mathrm{pb})\end{array}$ \\
\hline \multirow{2}{*}{$G A P D H$} & \multirow{2}{*}{$\begin{array}{l}\text { Glyceraldehyde-3-phosphate } \\
\text { dehydrogenase }\end{array}$} & $\mathrm{F}$ & CCGTGTTCCCACTGTTGATGTT & \multirow{2}{*}{192} \\
\hline & & $\mathrm{R}$ & GCATCAAAGATGCTGGACCTGT & \\
\hline \multirow{2}{*}{$\alpha-T U B$} & \multirow{2}{*}{ Alpha-tubulin } & $\mathrm{F}$ & CTGACAGCTTCCCTGAGGTTTGAT & \multirow{2}{*}{179} \\
\hline & & $\mathrm{R}$ & TCAAAGGCGCTGTTGGTGATCT & \\
\hline \multirow{2}{*}{ PCS } & \multirow{2}{*}{ Phytochelatin synthase } & $\mathrm{F}$ & GCTATGTGGTAGTTGCTCGTCTTC & \multirow{2}{*}{195} \\
\hline & & $\mathrm{R}$ & ACCACGGTTCCTGAGATAACAGTC & \\
\hline \multirow{2}{*}{$E F 1 \alpha$} & \multirow{2}{*}{ Elongation factor- 1 alpha } & $\mathrm{F}$ & AGGCTGTCCGCAGTGTTCAAAT & \multirow{2}{*}{178} \\
\hline & & $\mathrm{R}$ & TCACACGACTGGACATACTCGTTG & \\
\hline \multirow{2}{*}{$A P X$} & \multirow{2}{*}{ Ascorbate peroxidase } & $\mathrm{F}$ & TCCAACCGTTGAGTTCATCCCT & \multirow{2}{*}{199} \\
\hline & & $\mathrm{R}$ & ACCGTCAAACCCAGACCTTTCA & \\
\hline \multirow{2}{*}{$\mathrm{Cu} / \mathrm{Zn} S O D$} & \multirow{2}{*}{$\begin{array}{l}\mathrm{Cu} / \mathrm{Zn} \text { Superoxide } \\
\text { dismutase }\end{array}$} & $\mathrm{F}$ & TTTCCAGTCGCTCCGAATTGTCTC & \multirow{2}{*}{186} \\
\hline & & $\mathrm{R}$ & AGTCCAGTGATACGAACGTTCACC & \\
\hline \multirow{2}{*}{ MT } & \multirow{2}{*}{ Metallothionein } & $\mathrm{F}$ & CCAGTGCAGATCAGTATCAGACCA & \multirow{2}{*}{176} \\
\hline & & $\mathrm{R}$ & CTCGTCCATCTCAGGGTACATCTT & \\
\hline
\end{tabular}

\subsection{Statistical Analysis}

Statistical analyses were carried out with StatSoft Inc. (2004) STATISTICA (data analysis software system), version 7 (www.statsoft.com) (Tulsa, OK, USA). Differences between treatments were evaluated using a factorial analysis of variance (ANOVA). The Tukey test was used to observe differences between groups. Statistical significance was determined at $p<0.05$. 


\section{Results}

\subsection{Bacteria and Fungi Identification and Arsenic Resistance}

The bacterial isolates B4 and B10 showed 100\% identity with Pseudomonas gessardii (Accession Number MH398505.1) and 100\% identity with Brevundimonas intermedia (Accession number KR811205.1), respectively. The fungal isolates V7 and V8 showed 100\% identity with Fimetariella rabenhortii (Accession Number HQ406808) and Hormonema viticola (Accession number NR137620.1), respectively.

Minimum inhibition concentrations (MICs) of fungal and bacterial strains to As are shown in Table 3. Both bacterial strains showed resistance to high concentrations of sodium arsenate. P. gessardii and B. intermedia were able to grow in LB medium supplemented with 7000 and $6000 \mathrm{mg} \cdot \mathrm{L}^{-1}$ of $\mathrm{As}$, respectively. In the case of both fungal strains, F. rabenhortii and $H$. viticola were able to grow in $2500 \mathrm{mg} \cdot \mathrm{L}^{-1}$ of As.

Table 3. Molecular identification, siderophore production, phosphate solubilization and minimum inhibition concentration (MIC) of the isolated bacterial and fungal strains, and the production of indoleacetic acid (IAA) by bacterial and fungi isolates in LB (Luria-Bertani) medium and 1/7 PDB (Potato Dextrose Broth), respectively, supplemented with concentrations of 0 and $250 \mathrm{mg} \cdot \mathrm{L}^{-1}$ of arsenic.

\begin{tabular}{|c|c|c|c|c|c|c|c|c|}
\hline \multirow{2}{*}{ Strains } & \multirow{2}{*}{$\begin{array}{c}\text { Molecular } \\
\text { Identification }\end{array}$} & \multirow{2}{*}{$\begin{array}{c}\text { Close Match } \\
\text { Accession } \\
\text { Number }\end{array}$} & \multicolumn{2}{|c|}{$\operatorname{MIC}\left(\mathrm{mg} \cdot \mathrm{L}^{-1}\right)$} & \multicolumn{2}{|c|}{ IAA As $\left(\mathrm{mg} \cdot \mathrm{L}^{-1}\right)$} & \multirow{2}{*}{$\begin{array}{l}\text { Siderophore } \\
\text { Production }+\end{array}$} & \multirow{2}{*}{$\begin{array}{c}\text { Phosphate } \\
\text { Solubilization }\end{array}$} \\
\hline & & & AsV & AsIII & 0 & 250 & & \\
\hline B4 & $\begin{array}{l}\text { Pseudomonas } \\
\text { gessardii }\end{array}$ & MH398505.1 & 7000 & 1500 & 0 & 0 & + & + \\
\hline B10 & $\begin{array}{l}\text { Brevundimonas } \\
\text { intermedia }\end{array}$ & KR811205.1 & 6000 & 1500 & $\begin{array}{c}52.32 \pm \\
0.9^{\mathrm{a}}\end{array}$ & $\begin{array}{c}52.45 \pm \\
0.3^{\mathrm{a}}\end{array}$ & - & - \\
\hline V7 & $\begin{array}{c}\text { Fimetariella } \\
\text { rabenhortii }\end{array}$ & HQ406808 & 2500 & 750 & $\begin{array}{l}40.5 \pm \\
0.74^{b}\end{array}$ & $\begin{array}{l}41.6 \pm \\
0.42^{b}\end{array}$ & - & - \\
\hline V8 & $\begin{array}{c}\text { Hormonema } \\
\text { viticola }\end{array}$ & NR137620.1 & 2500 & 720 & $\begin{array}{c}57.64 \\
\pm 1.06^{\mathrm{a}}\end{array}$ & $\begin{array}{c}56.62 \pm \\
2.78^{\mathrm{a}}\end{array}$ & - & - \\
\hline
\end{tabular}

† Siderophore: $(+)$ production, $(-)$ no production; $\ddagger$ Phosphate solubilization (+), no solubilization (-), Different letters denote statistically significant differences $(p<0.05)$.

\subsection{Screening of Potential Plant Growth-Promoting Traits}

The production of low molecular weight molecule, iron-chelating siderophores by the arsenic-resistant bacterial and fungal strains detected by the Chrome azurol S (CAS) assay are shown in Table 3. Only P. gessardii produced changes in medium coloration to orange, which is consistent with chemical testing for hydroxamate siderophores [41]. The bacteria and fungi isolates screened for IAA production showed that one bacterial strain and both fungi were able to utilize L-tryptophan as a precursor to producing IAA (Table 3), and the presence of arsenic had no negative effect on IAA production. B. intermedia produced $52.45 \mu \mathrm{g} \mathrm{mL}^{-1}$ and P. gessardii had no production. Meanwhile, $H$. viticola produced the highest IAA concentration $\left(57.54 \mu \mathrm{g} \mathrm{mL}^{-1}\right)$, and As supplementation did not affect IAA production by F. rabenhortii and H. viticola. Regarding phosphate solubilization, only P. gessardii was able to solubilize phosphate in solid culture (Table 3), showing a clear formation of a solubilization halo.

\subsection{Shoot and Root Dry Biomass}

The plants that grew in the soil supplemented with As showed lower shoot and root dry biomass and decreased between $30 \%$ and 50\% approximately (Figure 1); nevertheless, the treatment with the mixture of P. gessardii plus B. intermedia (B4 + B10) showed a significant increase compared to the control. Also, shoot dry weight increased with the inoculation of F. rabenhortii (V7) and there is a positive tendency with the inoculation of B. intermedia plus P. gessardii (B4 + B10) when As was not added to the soil. Arsenic content (Table A1) in the shoot and root of Triticum aestivum without the addition of As and the addition of $300 \mathrm{mg} \cdot \mathrm{Kg}^{-1}$ of As showed no differences among the treatments. 


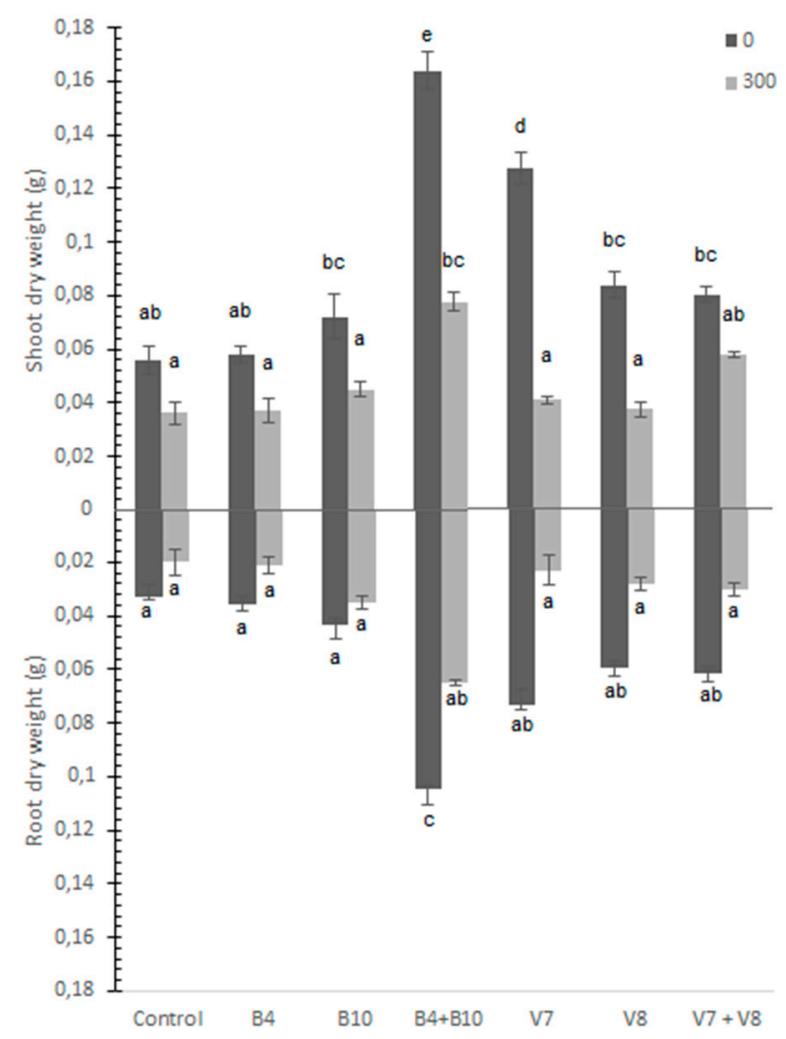

Figure 1. Shoot and root dry biomass of Triticum aestivum grown in a soil supplemented with $300 \mathrm{mg} \cdot \mathrm{Kg}^{-1}$ of As and inoculated with Pseudomonas gessardii (B4), B. intermedia (B10), the mixture of both (B4 + B10), F. rabenhortii (V7), H. viticola (V8), and the mixture of both (V7 + V8). The standard deviation is indicated by different bars and letters show statistically significant differences $(p<0.05)$.

\subsection{Soil Enzyme Activities}

Acid phosphatase activity, associated with phosphate solubilization, was substantially increased between $56 \%$ and $145 \%$ in treatments B. intermedia, F. rabenhortii, and F. rabenhortii plus $H$. viticola in soils without added As, and approximately $92 \%$ with the inoculation of B. intermedia and H. viticola in soils supplemented with As (Table 4). For $\beta$-glucosidase activity and fluorescein diacetate activity (FDA) hydrolysis, there were no significant differences between treatments.

\subsection{Relative Quantification of Gene Expression}

The expression of genes involved in the stress response caused by As in wheat leaves was analyzed. The control treatment (without the addition of As) was defined as a calibrator and is expressed in the graphs with the value 1 ; therefore, all the treatments were compared with the control. Figure $2 \mathrm{a}$ shows the relative expression of the gene that codes for a metallothionein (MT), which showed a 5 -fold increase when the plants were inoculated with B. intermedia (B10) and a 10-fold increase when As was added. Inoculation with P. gessardii plus B. intermedia (B4 + B10), and the fungus $F$. rabenhortii plus $H$. viticola (V7 + V8) showed up to a 35-fold increase. Increased expression was observed in all treatments, except with inoculation with P. gessardii (B4), when the soil was supplemented with $300 \mathrm{mg} \cdot \mathrm{Kg}^{-1}$ of As. The relative expression of the superoxide dismutase $(\mathrm{Zn} / \mathrm{Cu} S O D)$ and ascorbate peroxidase $(A P X)$ genes (Figure $2 b, c)$ increased in plants inoculated with P. gessardii plus B. intermedia (B4 + B10) and the fungi $F$. rabenhortii (V7) without the As added.

The relative expression of the phytochelatin synthase (PCS) gene (Figure $2 \mathrm{~d}$ ) indicates a tendency to decrease when bacteria were inoculated separately in soils with or without the supplementation with As. As the inoculation of P. gessardii plus B. intermedia (B4 + B10) increased, the relative expression of PCS decreased compared to the control. 
Table 4. $\beta$-glucosidase, acid phosphatase and hydrolysis of fluorescein diacetate activity (FDA) in rhizospheric soil of T. aestivum without the addition of As and the addition of $300 \mathrm{mg} \cdot \mathrm{Kg}^{-1} \mathrm{of}$ As.

\begin{tabular}{|c|c|c|c|}
\hline & $\begin{array}{c}\beta \text {-Gucosidase }(\mu \text { moles } \\
\left.p \text {-Nitrophenol } \mathrm{g}^{-1} \mathrm{~h}^{-1}\right)\end{array}$ & $\begin{array}{c}\text { FDA }(\mu g \\
\left.\text { Fluorescein } g^{-1}\right)\end{array}$ & $\begin{array}{c}\text { Acid Phosphatase ( } \mu \text { moles } \\
p \text {-Nitrophenol } \mathrm{g}^{-1} \mathrm{~h}^{-1} \text { ) }\end{array}$ \\
\hline \multicolumn{4}{|c|}{ Soil without As Added } \\
\hline Control & $96.01 \pm 8.23$ & $12.8 \pm 1.17$ & $82.09 \pm 8.01^{\mathrm{a}, \mathrm{b}, \mathrm{c}}$ \\
\hline B4 & $84.39 \pm 11.41$ & $13.02 \pm 1.05$ & $90.06 \pm 6.18^{\mathrm{a}, \mathrm{b}, \mathrm{c}, \mathrm{d}}$ \\
\hline B10 & $106.21 \pm 13.45$ & $14.03 \pm 3.17$ & $128.37 \pm 2.88^{\mathrm{d}, \mathrm{e}, \mathrm{f}}$ \\
\hline $\mathrm{B} 4+\mathrm{B} 0$ & $121.35 \pm 10.19$ & $14.14 \pm 1.65$ & $123.78 \pm 15.08^{\mathrm{c}, \mathrm{d}, \mathrm{e}, \mathrm{f}}$ \\
\hline V7 & $134.32 \pm 4.3$ & $15.4 \pm 1.3$ & $181.95 \pm 6.53 \mathrm{~g}, \mathrm{~h}$ \\
\hline V8 & $97.7 \pm 7.43$ & $12.24 \pm 0.93$ & $113.37 \pm 4.66^{\mathrm{c}, \mathrm{d}, \mathrm{e}, \mathrm{f}}$ \\
\hline $\mathrm{V} 7+\mathrm{V} 8$ & $123.1 \pm 10.1$ & $11.02 \pm 0.97$ & $201.48 \pm 10.42^{h}$ \\
\hline \multicolumn{4}{|c|}{ Soil with As Added } \\
\hline Control & $99.32 \pm 21.27$ & $12.15 \pm 1.74$ & $60.06 \pm 5.57^{\mathrm{a}}$ \\
\hline B4 & $109.18 \pm 21$ & $12.3 \pm 0.85$ & $70.67 \pm 5.4^{\mathrm{a}, \mathrm{b}}$ \\
\hline B10 & $144.32 \pm 18.54$ & $13.45 \pm 1.36$ & $150 \pm 4.89^{\mathrm{e}, \mathrm{f}, \mathrm{g}}$ \\
\hline $\mathrm{B} 4+\mathrm{B} 0$ & $114.25 \pm 15.63$ & $13.91 \pm 2.77$ & $109.72 \pm 6.28^{b, c, d, e}$ \\
\hline V7 & $109.32 \pm 1.4$ & $11.68 \pm 0.52$ & $96.41 \pm 7.38^{\mathrm{a}, \mathrm{b}, \mathrm{c}, \mathrm{d}}$ \\
\hline V8 & $138.51 \pm 8.41$ & $16.8 \pm 1.99$ & $158.01 \pm 17.62^{f, g, h}$ \\
\hline $\mathrm{V} 7+\mathrm{V} 8$ & $117.97 \pm 6.75$ & $15.75 \pm 1.5$ & $114.39 \pm 8.33^{c, d, e, f}$ \\
\hline
\end{tabular}

B4, Pseudomonas gessardii; B10, Brevundimonas intermedia; Fimetariella rabenhortii, V7; Hormonema viticola (V8). Different letters denote statistically significant differences $(p<0.05)$.
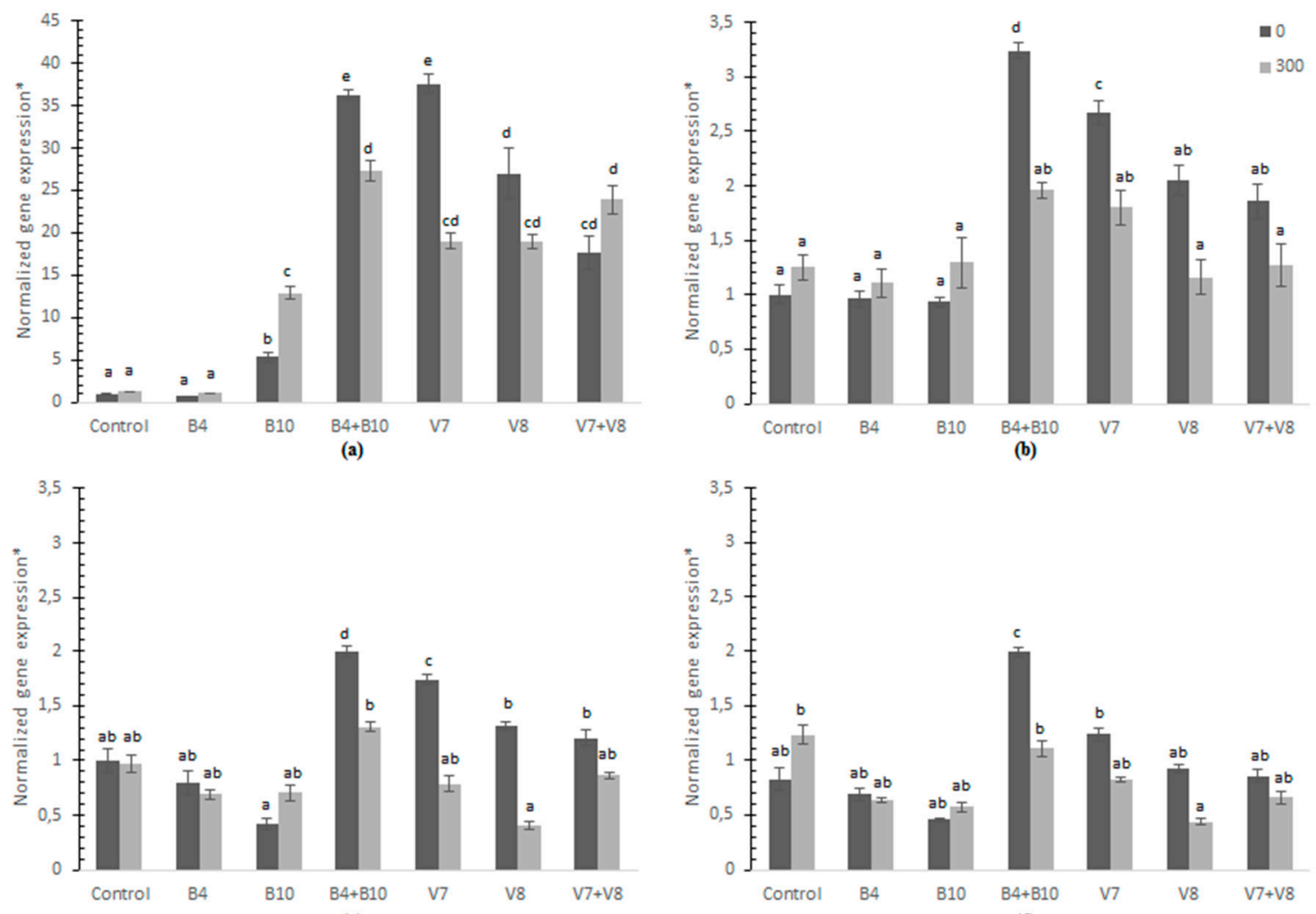

(c)

(d)

Figure 2. Relative expression of the metallothionein $(M T)$ (a), superoxide dismutase $(\mathrm{Zn} / \mathrm{Cu} S O D)(\mathbf{b})$, ascorbate peroxidase $(A P X)(\mathbf{c})$ and phytochelatin synthase $(P C S)(\mathbf{d})$ genes in T. aestivum leaves grown in a soil supplemented with $300 \mathrm{mg} \cdot \mathrm{Kg}^{-1}$ of As and inoculated with P. gessardii (B4), B. intermedia (B10), the mixture of both (B4 + B10), F. rabenhortii (V7), H. viticola (V8), the mixture of both (V7 + V8). The standard deviation is indicated by different bars and letters show statistically significant differences $(p<0.05)$. ${ }^{*}$ Normalized to GAPDH and $\alpha$-TUB. 


\section{Discussion}

Arsenic is toxic to bacteria and fungi, as well as to other life forms. The isolates P. gessardii, B. intermedia and the fungi $F$. rabenhortii and $H$. viticola can resist high concentrations of As, either as $\mathrm{As}(\mathrm{III})$ or $\mathrm{As}(\mathrm{V})$. This characteristic is likely associated with evolutionary adaptation to soil highly contaminated with a variety of heavy metals from which they were isolated, and these stressful conditions have led them to develop mechanisms to resist and tolerate restrictive edaphic conditions [42]. To cope with the As toxicity, As resistance (ars) genes can be found in the genome of nearly every bacterial species sequenced to date [43], and both, bacteria and fungi have the ability to tolerate As by several mechanisms including valence transformation, extra and intracellular precipitation, active uptake and biosorption [44]. Several studies have shown that the genera Pseudomonas [45,46] can reduce or oxidize arsenic and Tsubouchi and Kaneko [47] showed that Brevundimonas possess the ars operon that allow them to tolerate As by reduction or oxidation, among other processes. In regard to the fungi used in our study, there is no information about how arsenics metabolize.

Interactions between plants and microorganisms in the rhizosphere play a key role in growth of plants, and in nutrient uptake and transport [48]. Several studies have shown that plants' adaptation to local environmental stress is closely related to the microorganisms that are in their surroundings [49]. Thereby, the evaluation of plant growth-promoting traits is of the utmost importance since these minimize toxic effects of abiotic and biotic stress including heavy metals in our study. Bacterial and fungal strains showed that $P$. gessardii produced siderophores and solubilized phosphate, and B. intermedia, F. rabenhortii and $H$. viticola were able to synthetize indoleacetic acid (IAA). It has been reported that As-resistant microorganisms belonging to diverse species possess plant growth-promoting traits, Das, et al. [50] and Xu, et al. [51] showed a variety of bacteria genera, such as Brevundimonas, Pseudomonas, Comamona, Bacillus, among others, that were able to produce siderophores, IAA and are capable of solubilizing phosphate.

Because these microorganisms were isolated from multicontaminated soil, they have the advantage of being adapted to this stressful condition and the production of IAA was not affected by the presence of As in the medium. In fact, this was increased in the case of F. rabernhortii. Carlos, et al. [52] showed that the production of IAA could show a 2-fold increase and this can happen with several other heavy metals. These characteristics are likely to play a key role in the adaptation of plants to a new environment [53] as a direct mechanism to promote tolerance and growth, because siderophores make iron available for plants, even under conditions of limited essential metal availability [54], and together with an effective inducer of plant growth such as IAA [55] will contribute to the adaptation of plants in heavy metal and As polluted soil [56].

In the present study, the growth of T. aestivum showed an inhibition of shoot and root dry weight due to the presence of a high level of As. In fact, this growth reduction induced by As is known to be due to the inactivation of enzymes by the binding of As with -SH protein groups with detrimental effects on protein function [16], oxidative stress, and by deterioration in other cell functions [57,58]. Although the high As the concentration added to the soil negatively affected plant growth, inoculation with $B$. intermedia, $H$. viticola and $F$. rabenhortii plus $H$. viticola had a tendency to show an improved positive effect on plant biomass when As was not added to the soil, and inoculation with B. intermedia plus $P$. gessardii and $F$. rabenhortii did increase plant growth in these conditions; it is important to note that the soil used in this experiment already had high concentrations of heavy metals (Table 1) and thus the microorganisms used could help in this type of condition but not with an excess of As. The inoculation of B. intermedia plus P. gessardii and F. rabenhortii increased the dry biomass of $T$. aestivum in the control soil. This joint effect can occur due to the metabolites, such as IAA, siderophores and phosphate solubilization that both microorganisms release and that can be complementary, having a synergistic effect [59]. IAA regulates growth and developmental processes [60]. Therefore, it directly intervenes in the increase in plant growth. Furthermore, P. gessardii showed an ability to solubilize phosphate and produce siderophores, likely self-regulating the iron in the soil and reducing the toxicity of arsenic (V) by increasing the iron supply to the plant [61]. In addition, the concentration of heavy 
metals and arsenic found in this soil interferes with the absorption of several nutrients such as $\mathrm{Fe}$ and $\mathrm{P}$, thus inhibiting plant growth. In this context, microorganisms that have the ability to solubilize phosphate can provide soluble forms of $\mathrm{P}$ for plants and make an important contribution to the growth-promoting effect in plants [62]. Likewise, B. intermedia as well as both fungi produced a high concentration of IAA. This phytohormone directly stimulates plant cell elongation and cell division [63], which leads to a stimulation of plant growth and reduces the stress caused by soil pollution with heavy metals and arsenic.

The transcription of genes involved in the stress response by heavy metals in wheat leaves showed that the relative expression of the genes $M T, S O D, A P X$ and $P C S$ was stimulated in the leaves when $P$. gessardii plus $B$. intermedia and in some cases $F$. rabenhortii were present. It is reported that the IAA released by rhizobacteria, in this case, $B$. intermedia, could directly promote the growth of roots by stimulating elongation of the plant cells or increasing cell division [64], which may enhance the root As absorption. Moreover, siderophore production by P. gessardii may mobilize $\mathrm{As}(\mathrm{V})$ in the soil in the process of taking up iron ions [65], which renders As more soluble and bioavailable to plants, which may explain the overexpression of these genes when P. gessardii plus B. intermedia where inoculated together. Even though it could be an increase in the exposure to inorganic As and the induction of reactive oxygen species (ROS), these microorganisms are stimulating the defenses against ROS by increasing the production of antioxidant enzymes and $M T$ and $P C S$, and can be corroborated with the increase in dry biomass (Figure 1). Abercrombie, et al. [66] found in Arabidopsis thaliana that the $\mathrm{Zn} / \mathrm{Cu} S O D$ class is at least doubled in the presence of As $(\mathrm{V})$. Therefore, the enzymatic mechanisms effectively counteract the oxidative stress induced by As. Likewise, the variation in enzymatic antioxidant activities is related to the availability of nutrients in the soil, since some of these are metalloenzymes and their activities are determined by the availability of heavy metals [67].

\section{Conclusions}

Although not all the microorganisms studied had a beneficial effect for the plants, inoculation with the bacterium P. gessardii plus B. intermedia promoted growth in wheat plant and produced a higher antioxidant enzymatic response to the supplementation of the soil with As, showing the potential of the microorganisms isolated from polluted soil to contribute to the restoration of contaminated soils. In this order, further studies will be focused on understanding the nature of the mechanisms involved in the interactions between other plants and microorganisms and finding applications in the development of bioremediation strategies. Furthermore, the application of heavy metal-resistant and plant-beneficial bacteria and fungi can be considered as a tool for bioremediation strategies with great economic and ecological importance.

Author Contributions: Conceptualization, J.S., A.F., L.A. and C.A.; methodology, J.S. and J.O.; validation, J.S., A.F. and H.H.; formal analysis, J.S., J.O. and H.H.; investigation, J.S.; writing-original draft preparation, J.S.; writing - review and editing, J.S., T.C.C., H.H., L.A. and C.A.; supervision, C.A.

Funding: This research was funded by Fondo Nacional de Desarrollo, Científico y Tecnológico, FONDECYT 1170931, and Comisión Nacional de Investigación Científica y Tecnológica, CONICYT Doctoral Scholarship 21140503.

Conflicts of Interest: The authors declare no conflict of interest. 


\section{Appendix A}

Table A1. Arsenic content $\left(\mathrm{mg} \cdot \mathrm{Kg}^{-1}\right)$ in the shoot and root of Triticum aestivum without the addition of As and the addition of $300 \mathrm{mg} \cdot \mathrm{Kg}^{-1}$ of As. Control: no inoculation of microorganisms; P. gessardii (B4), B. intermedia (B10), the mixture of both (B4 + B10), F. rabenhortii (V7), H. viticola (V8), and the mixture of both $(\mathrm{V} 7+\mathrm{V} 8)$.

\begin{tabular}{|c|c|c|c|c|c|c|c|}
\hline Arsenic Content (mg Kg $\left.{ }^{-1}\right)$ & Control & B4 & B10 & $\mathrm{B} 4+\mathrm{B} 10$ & V7 & V8 & $\mathrm{V7}+\mathrm{V8}$ \\
\hline \multicolumn{8}{|l|}{ Shoot } \\
\hline Control & 0.37 & 0.51 & 0.41 & 0.6 & 0.52 & 0.45 & 0.42 \\
\hline $300 \mathrm{mg} \mathrm{Kg}^{-1}$ & 8.83 & 6.79 & 6.13 & 6.11 & 7.13 & 6.07 & 6.17 \\
\hline \multicolumn{8}{|l|}{ Root } \\
\hline Control & 0.407 & 0.5967 & 0.4879 & 0.72 & 0.5772 & 0.495 & 0.4998 \\
\hline $300 \mathrm{mg} \mathrm{Kg}^{-1}$ & 9.0949 & 7.9443 & 7.7238 & 7.2709 & 8.2708 & 8.0124 & 8.2061 \\
\hline
\end{tabular}

\section{References}

1. Leist, M.; Casey, R.; Caridi, D. The management of arsenic wastes: Problems and prospects. J. Hazard. Mater. 2000, 76, 125-138. [CrossRef]

2. Mandal, B.K.; Suzuki, K.T. Arsenic round the world: A review. Talanta 2002, 58, 201-235. [CrossRef]

3. EPA U. Arsenic, inorganic (CASRN 7440-38-2). 2007.

4. Smedley, P.; Kinniburgh, D. A review of the source, behaviour and distribution of arsenic in natural waters. Appl. Geochem. 2002, 17, 517-568. [CrossRef]

5. Meharg, A. Integrated tolerance mechanisms: Constitutive and adaptive plant responses to elevated metal concentrations in the environment. Plant Cell Environ. 1994, 17, 989-993. [CrossRef]

6. Kamiya, K.; Cruse, W.B.; Kennard, O. The arsonomethyl group as an analogue of phosphate. An X-ray investigation. Biochem. J. 1983, 213, 217-223. [CrossRef] [PubMed]

7. Carbonell-Barrachina, A.; Burlo, F.; Burgos-Hernandez, A.; Lopez, E.; Mataix, J. The influence of arsenite concentration on arsenic accumulation in tomato and bean plants. Sci. Hortic. 1997, 71, 167-176. [CrossRef]

8. Ahmed, F.S.; Killham, K.; Alexander, I. Influences of arbuscular mycorrhizal fungus Glomus mosseae on growth and nutrition of lentil irrigated with arsenic contaminated water. Plant Soil 2006, 283, 33. [CrossRef]

9. Srivastava, S.; Srivastava, A.K.; Suprasanna, P.; D'souza, S. Comparative biochemical and transcriptional profiling of two contrasting varieties of Brassica juncea L. in response to arsenic exposure reveals mechanisms of stress perception and tolerance. J. Exp. Bot. 2009, 60, 3419-3431. [CrossRef]

10. Garg, N.; Singla, P. Arsenic toxicity in crop plants: Physiological effects and tolerance mechanisms. Environ. Chem. Lett. 2011, 9, 303-321. [CrossRef]

11. Finnegan, P.; Chen, W. Arsenic toxicity: The effects on plant metabolism. Front. Physiol. 2012, 3, 182. [CrossRef]

12. Stoeva, N.; Bineva, T. Oxidative changes and photosynthesis in oat plants grown in As-contaminated soil. Bulg J. Plant Physiol 2003, 29, 87-95.

13. Zhao, F.J.; McGrath, S.P.; Meharg, A.A. Arsenic as a food chain contaminant: Mechanisms of plant uptake and metabolism and mitigation strategies. Annu. Rev. Plant Biol. 2010, 61, 535-559. [CrossRef] [PubMed]

14. Gupta, D.; Huang, H.; Yang, X.; Razafindrabe, B.; Inouhe, M. The detoxification of lead in Sedum alfredii H. is not related to phytochelatins but the glutathione. J. Hazard. Mater. 2010, 177, 437-444. [CrossRef]

15. Wickes, W.; Wiskish, J. Arsenate uncoupling of oxidative phosphorylation in isolated plant mitochondria. Funct. Plant Biol. 1976, 3, 153-162. [CrossRef]

16. Flora, S.J. Arsenic-induced oxidative stress and its reversibility. Free Radic. Biol. Med. 2011, 51, $257-281$. [CrossRef]

17. Sharma, I. Arsenic induced oxidative stress in plants. Biologia 2012, 67, 447-453. [CrossRef]

18. Awasthi, S.; Chauhan, R.; Dwivedi, S.; Srivastava, S.; Srivastava, S.; Tripathi, R.D. A consortium of alga (Chlorella vulgaris) and bacterium (Pseudomonas putida) for amelioration of arsenic toxicity in rice: A promising and feasible approach. Environ. Exp. Bot. 2018, 150, 115-126. [CrossRef] 
19. Srivastava, S.; Singh, N. Mitigation approach of arsenic toxicity in chickpea grown in arsenic amended soil with arsenic tolerant plant growth promoting Acinetobacter sp. Ecol. Eng. 2014, 70, 146-153. [CrossRef]

20. Pandey, N.; Bhatt, R. Role of soil associated Exiguobacterium in reducing arsenic toxicity and promoting plant growth in Vigna radiata. Eur. J. Soil Biol. 2016, 75, 142-150. [CrossRef]

21. Hansda, A.; Kumar, V.; Anshumali, A.; Usmani, Z. Phytoremediation of heavy metals contaminated soil using plant growth promoting rhizobacteria (PGPR): A current perspective. Recent Res. Sci. Technol. 2014, 6.

22. Glick, B.R. Using soil bacteria to facilitate phytoremediation. Biotechnol. Adv. 2010, 28, 367-374. [CrossRef] [PubMed]

23. Kuffner, M.; De Maria, S.; Puschenreiter, M.; Fallmann, K.; Wieshammer, G.; Gorfer, M.; Strauss, J.; Rivelli, A.; Sessitsch, A. Culturable bacteria from Zn-and Cd-accumulating Salix caprea with differential effects on plant growth and heavy metal availability. J. Appl. Microbiol. 2010, 108, 1471-1484. [CrossRef] [PubMed]

24. Liu, W.; Yang, C.; Shi, S.; Shu, W. Effects of plant growth-promoting bacteria isolated from copper tailings on plants in sterilized and non-sterilized tailings. Chemosphere 2014, 97, 47-53. [CrossRef] [PubMed]

25. Ginocchio, R. Effects of a copper smelter on a grassland community in the Puchuncav1 Valley, Chile. Chemosphere 2000, 41, 15-23. [CrossRef]

26. Fuentes, A.; Almonacid, L.; Ocampo, J.A.; Arriagada, C. Synergistic interactions between a saprophytic fungal consortium and Rhizophagus irregularis alleviate oxidative stress in plants grown in heavy metal contaminated soil. Plant Soil 2016, 407, 355-366. [CrossRef]

27. Walkley, A.; Black, I.A. An examination of the Degtjareff method for determining soil organic matter, and a proposed modification of the chromic acid titration method. Soil Sci. 1934, 37, 29-38. [CrossRef]

28. Olsen, S. Anion resin extractable phosphorus. Methods Soil Anal. 1982, 2, 423-424.

29. Mingorance, M. Focused microwave-assisted digestion of vegetal materials for the determination of essential mineral nutrients. Anal. Bioanal. Chem. 2002, 373, 153-158. [CrossRef]

30. Bissett, J.; Widden, P. An automatic, multichamber soil-washing apparatus for removing fungal spores from soil. Can. J. Microbiol. 1972, 18, 1399-1404. [CrossRef]

31. Banerjee, S.; Datta, S.; Chattyopadhyay, D.; Sarkar, P. Arsenic accumulating and transforming bacteria isolated from contaminated soil for potential use in bioremediation. J. Environ. Sci. Health Part A 2011, 46, 1736-1747. [CrossRef]

32. White, T.J.; Bruns, T.; Lee, S.; Taylor, J. Amplification and direct sequencing of fungal ribosomal RNA genes for phylogenetics. PCR Protoc. A Guide Methods Appl. 1990, 18, 315-322.

33. Herrera, H.; Valadares, R.; Contreras, D.; Bashan, Y.; Arriagada, C. Mycorrhizal compatibility and symbiotic seed germination of orchids from the Coastal Range and Andes in south central Chile. Mycorrhiza 2017, 27, 175-188. [CrossRef]

34. Milagres, A.M.; Machuca, A.; Napoleao, D. Detection of siderophore production from several fungi and bacteria by a modification of chrome azurol S (CAS) agar plate assay. J. Microbiol. Methods 1999, 37, 1-6. [CrossRef]

35. Schwyn, B.; Neilands, J. Universal chemical assay for the detection and determination of siderophores. Anal. Biochem. 1987, 160, 47-56. [CrossRef]

36. Khalid, A.; Arshad, M.; Zahir, Z. Screening plant growth-promoting rhizobacteria for improving growth and yield of wheat. J. Appl. Microbiol. 2004, 96, 473-480. [CrossRef]

37. Ahemad, M.; Khan, M.S. Plant growth promoting activities of phosphate-solubilizing Enterobacter asburiae as influenced by fungicides. Eur. Asian. J. Bio. Sci. 2010, 4, 88-95. [CrossRef]

38. Gianfreda, L.; Rao, M.A.; Piotrowska, A.; Palumbo, G.; Colombo, C. Soil enzyme activities as affected by anthropogenic alterations: Intensive agricultural practices and organic pollution. Sci. Total Environ. 2005, 341, 265-279. [CrossRef]

39. Eivazi, F.; Tabatabai, M. Glucosidases and galactosidases in soils. Soil Biol. Biochem. 1988, 20, 601-606. [CrossRef]

40. Adam, G.; Duncan, H. Development of a sensitive and rapid method for the measurement of total microbial activity using fluorescein diacetate (FDA) in a range of soils. Soil Biol. Biochem. 2001, 33, 943-951. [CrossRef]

41. Pérez-Miranda, S.; Cabirol, N.; George-Téllez, R.; Zamudio-Rivera, L.; Fernández, F. O-CAS, a fast and universal method for siderophore detection. J. Microbiol. Methods 2007, 70, 127-131. [CrossRef]

42. Rajkumar, M.; Ae, N.; Prasad, M.N.V.; Freitas, H. Potential of siderophore-producing bacteria for improving heavy metal phytoextraction. Trends Biotechnol. 2010, 28, 142-149. [CrossRef] 
43. Yang, H.C.; Rosen, B.P. New mechanisms of bacterial arsenic resistance. Biomed. J. 2016, 39, 5-13. [CrossRef]

44. Srivastava, P.K.; Vaish, A.; Dwivedi, S.; Chakrabarty, D.; Singh, N.; Tripathi, R.D. Biological removal of arsenic pollution by soil fungi. Sci. Total Environ. 2011, 409, 2430-2442. [CrossRef]

45. Liao, V.H.C.; Chu, Y.J.; Su, Y.C.; Hsiao, S.Y.; Wei, C.C.; Liu, C.W.; Liao, C.M.; Shen, W.C.; Chang, F.J. Arsenite-oxidizing and arsenate-reducing bacteria associated with arsenic-rich groundwater in Taiwan. J. Contam. Hydrol. 2011, 123, 20-29. [CrossRef]

46. Zhang, Z.; Yin, N.; Cai, X.; Wang, Z.; Cui, Y. Arsenic redox transformation by Pseudomonas sp. HN-2 isolated from arsenic-contaminated soil in Hunan, China. J. Environ. Sci. 2016, 47, 165-173. [CrossRef]

47. Tsubouchi, T.; Kaneko, Y. Draft genome sequence of the arsenic-resistant bacterium Brevundimonas denitrificans TAR-002T. Genome Announc. 2017, 5, e01326-17. [CrossRef]

48. Upadhyay, M.K.; Yadav, P.; Shukla, A.; Srivastava, S. Utilizing the potential of microorganisms for managing arsenic contamination: A feasible and sustainable approach. Front. Environ. Sci. 2018, 6, 24. [CrossRef]

49. Vacheron, J.; Desbrosses, G.; Bouffaud, M.L.; Touraine, B.; Moënne-Loccoz, Y.; Muller, D.; Legendre, L.; Wisniewski-Dyé, F.; Prigent-Combaret, C. Plant growth-promoting rhizobacteria and root system functioning. Front. Plant Sci. 2013, 4, 356. [CrossRef]

50. Das, S.; Jean, J.S.; Kar, S.; Chou, M.L.; Chen, C.Y. Screening of plant growth-promoting traits in arsenic-resistant bacteria isolated from agricultural soil and their potential implication for arsenic bioremediation. J. Hazard. Mater. 2014, 272, 112-120. [CrossRef]

51. Xu, J.Y.; Han, Y.H.; Chen, Y.; Zhu, L.J.; Ma, L.Q. Arsenic transformation and plant growth promotion characteristics of As-resistant endophytic bacteria from As-hyperaccumulator Pteris vittata. Chemosphere 2016, 144, 1233-1240. [CrossRef]

52. Carlos, M.H.J.; Stefani, P.V.Y.; Janette, A.M.; Melani, M.S.S.; Gabriela, P.O. Assessing the effects of heavy metals in ACC deaminase and IAA production on plant growth-promoting bacteria. Microbiol. Res. 2016, 188, 53-61. [CrossRef]

53. Ma, Y.; Prasad, M.; Rajkumar, M.; Freitas, H. Plant growth promoting rhizobacteria and endophytes accelerate phytoremediation of metalliferous soils. Biotechnol. Adv. 2011, 29, 248-258. [CrossRef]

54. Dale, S.E.; Doherty-Kirby, A.; Lajoie, G.; Heinrichs, D.E. Role of siderophore biosynthesis in virulence of Staphylococcus aureus: Identification and characterization of genes involved in production of a siderophore. Infect. Immun. 2004, 72, 29-37. [CrossRef]

55. Wahyudi, A.T.; Astuti, R.P.; Widyawati, A.; Mery, A.; Nawangsih, A.A. Characterization of Bacillus sp. strains isolated from rhizosphere of soybean plants for their use as potential plant growth for promoting rhizobacteria. J. Microbiol. Antimicrob. 2011, 3, 34-40.

56. Welbaum, G.E.; Sturz, A.V.; Dong, Z.; Nowak, J. Managing soil microorganisms to improve productivity of agro-ecosystems. Crit. Rev. Plant Sci. 2004, 23, 175-193. [CrossRef]

57. Malik, J.A.; Goel, S.; Sandhir, R.; Nayyar, H. Uptake and distribution of arsenic in chickpea: Effects on seed yield and seed composition. Commun. Soil Sci. Plant Anal. 2011, 42, 1728-1738. [CrossRef]

58. Shri, M.; Kumar, S.; Chakrabarty, D.; Trivedi, P.K.; Mallick, S.; Misra, P.; Shukla, D.; Mishra, S.; Srivastava, S.; Tripathi, R.D. Effect of arsenic on growth, oxidative stress, and antioxidant system in rice seedlings. Ecotoxicol. Environ. Saf. 2009, 72, 1102-1110. [CrossRef]

59. Arriagada, C.; Aranda, E.; Sampedro, I.; Garcia-Romera, I.; Ocampo, J. Contribution of the saprobic fungi Trametes versicolor and Trichoderma harzianum and the arbuscular mycorrhizal fungi Glomus deserticola and G. claroideum to arsenic tolerance of Eucalyptus globulus. Bioresour. Technol. 2009, 100, 6250-6257. [CrossRef]

60. Wang, S.; Fu, J. Insights into auxin signaling in plant-pathogen interactions. Front. Plant Sci. 2011, $2,74$.

61. Ali, S.S.; Vidhale, N. Bacterial siderophore and their application: A review. Int. J. Curr. Microbiol. Appl. Sci. 2013, 2, 303-312.

62. Khan, M.S.; Zaidi, A.; Wani, P.A. Role of phosphate-solubilizing microorganisms in sustainable agriculture-a review. Agron. Sustain. Dev. 2007, 27, 29-43. [CrossRef]

63. Wang, Q.; Xiong, D.; Zhao, P.; Yu, X.; Tu, B.; Wang, G. Effect of applying an arsenic-resistant and plant growth-promoting rhizobacterium to enhance soil arsenic phytoremediation by Populus deltoides LH05-17. J. Appl. Microbiol. 2011, 111, 1065-1074. [CrossRef]

64. Minamisawa, K.; Fukai, K. Production of indole-3-acetic acid by Bradyrhizobium japonicum: A correlation with genotype grouping and rhizobitoxine production. Plant Cell Physiol. 1991, 32, 1-9. 
65. Drewniak, L.; Styczek, A.; Majder-Lopatka, M.; Sklodowska, A. Bacteria, hypertolerant to arsenic in the rocks of an ancient gold mine, and their potential role in dissemination of arsenic pollution. Environ. Pollut. 2008, 156, 1069-1074. [CrossRef]

66. Abercrombie, J.M.; Halfhill, M.D.; Ranjan, P.; Rao, M.R.; Saxton, A.M.; Yuan, J.S.; Stewart, C.N. Transcriptional responses of Arabidopsis thaliana plants to As (V) stress. BMC Plant Biol. 2008, 8, 87. [CrossRef]

67. Leão, G.A.; de Oliveira, J.A.; Felipe, R.T.A.; Farnese, F.S.; Gusman, G.S. Anthocyanins, thiols, and antioxidant scavenging enzymes are involved in Lemna gibba tolerance to arsenic. J. Plant Interact. 2014, 9, 143-151. [CrossRef]

(c) (C) 2019 by the authors. Licensee MDPI, Basel, Switzerland. This article is an open access article distributed under the terms and conditions of the Creative Commons Attribution (CC BY) license (http://creativecommons.org/licenses/by/4.0/). 